\title{
Cognitive Behavioral Therapy for Chronic Pain
}

\author{
Riska Afrina ${ }^{1}$, Azimatul Karimah ${ }^{1 *}$ \\ ${ }^{1}$ Department of Psychiatry, Faculty of Medicine, Universitas Airlangga - Dr. Soetomo General Hospital, Surabaya, \\ Indonesia, Indonesia
}

\section{A R T I C L E I N F O}

Article history:

Received 23 August 2019

Received in revised form 9

October 2019

Accepted 15 October 2019

Available online 31 October 2019

Keywords:

Chronic pain,

Cognitive behavioral therapy,

Pain management,

Efficacy.

*) Corresponding author:

uci.nugroho@gmail.com

\begin{abstract}
A B S T R A C T
Introduction: Pain is a complex stressor that has a major influence on several aspects of a person's physical, psychological, work and financial functions, especially in the form of chronic pain. The approach of chronic pain medically sometimes cannot solve the problem as a whole, thus management psychological approaches such as cognitive and behavioral therapy (CBT) is needed. Methods: We searched PubMed, Science Direct, and Google Scholar for search articles in English terms "chronic pain", "cognitive behavioral therapy", "pain management", and "efficacy". There were 40 articles, and took 8 articles from the last 5 years.

Results: The method of intervention was carried out with a cognitive-behavioral approach in the form of traditional CBT, telephone-based CBT, coping skills training, cognitive-behavioral based physical therapy or CBT-based self-management. The research parameters used to measure the success rate of the interventions were pain intensity, physical function, psychological pressure, disability, fatigue, quality of life, coping strategies, catastrophization, and depression. The duration of the study varied from 5 weeks to 10 weeks, with a variation of 20-60 minutes per therapy session, except in studies using group therapy can take up to 5-7 hours per day. Some studies also conducted evaluation at the third and six months after treatment. The aim of the CBT approach was to independently improve self-efficacy in pain management.

Conclusion: Cognitive behavioral approaches combined with other therapeutic modalities can improve the physical function of patients with chronic pain.
\end{abstract}

\section{Introduction}

Pain is a biological process that indicates a disruption or injury in the body. Pain prevents further damage due to excessive use of painful areas and also helps in the process of tissue physiological homeostasis. ${ }^{1}$ Pain that occurs repeatedly and has a prolonged healing time of more than 3 months is referred to as chronic pain. ${ }^{2}$

A survey in 15 countries by World Health Organization (WHO) in 1998 found that 22\% of patients in primary care facilities needed medical attention and treatment due to pain which had been experienced for 6 months or more, and the condition had significantly disrupted daily activities. $^{3}$

Pain can be caused by an acute illness, injury, or surgery, and will usually improve after receiving treatment. Chronic pain is a problem that is quite troublesome for the patients. Pain that persists and extends from the expected normal healing time can be a barrier to one's health. ${ }^{4}$ Chronic pain is a condition that is quite difficult to manage, where $60 \%$ of those who suffered from it still experience pain after 1 year of treatment, ${ }^{5}$ and clinical studies showed that severe depression was experienced by $85 \%$ of patients suffering from chronic pain. ${ }^{6}$

Recurrent pain could cause maladaptive cognition and behavior which in turn could deteriorate daily function, increase psychological stress, and could even prolong pain itself. ${ }^{1}$ Somatic symptoms such as fatigue, irritability, sleep disturbances, and reduced appetite often accompany chronic pain. In chronic pain, the emotional, motivational, cognitive, and psychosocial factors are more intense than the nociceptive related pain itself. ${ }^{2}$

Biomedical managements such as opioid administration and surgical procedures for chronic pain did not provide long-lasting benefits. The utilization of opioids for pain could increase psychological problems and risk of abuse. In addition, there are also concerns about disability in chronic pain patients who underwent surgery. Therefore, to help in obtaining long-lasting results in chronic pain management, an alternative approach is needed. ${ }^{7}$ The purpose of this review is to assess the efficacy of the CBT approach in adult patients with chronic pain.

\section{Methods}

We searched in PubMed, Science Direct, and Google Scholar for articles in English using the search terms "chronic pain" and "cognitive behavioral therapy", combined with additional search terms, "pain management", and "efficacy". The inclusion criteria in this review are "cognitive behavioral therapy" and "in adult patients with chronic pain." Under those keywords we found 40 articles, 
selected and took 8 articles from the last 5 years.

\section{Results}

From 8 articles we reviewed, 4 articles used the intervention group and the control group, 1 article used the qualitative design from a previous RCT (Randomized Control Trial) study, 1 article conducted a prospective cohort design, and 2 research articles were meta-analyzes of RCTs (Table.1). The sample was patients with chronic pain with various medical conditions including those who had undergone surgery. All participants, including those who received the intervention, continued the usual medical care regarding the condition of the pain.

The method of intervention was carried out with a cognitive-behavioral approach in the form of traditional CBT, telephone-based CBT, coping skills training, cognitive-behavioral based physical therapy or CBT-based self-management. Meanwhile, the control group included education, supportive care, pharmacotherapy, usual care, and waiting lists. Two RCT articles showed that CBT interventions were provided by trained nurses, and other studies were provided by trained therapists.

Research conducted by Rutledge, et al. (2018) on veterans with chronic pain found that both CBT interventions and supportive care by trained nurses showed a significant enhancement in decreasing pain severity and disability. This showed that nurses were able to provide pain-related behavioral therapy. There was also no greater benefit regarding interventions provided by nurses on interventions that required strong patient and caregiver relationships. ${ }^{8}$

The research parameters used to measure the success rate of the interventions were quite comprehensive, some of which were pain intensity, physical function, psychological pressure, disability, fatigue, quality of life, coping strategies, catastrophization, and depression. In addition to measuring the results of pain, there were studies that have also tested mediators that affect pain relief related to the intervention given.

Åkerblom, et al. (2015) have mentioned that many things mediated changes in pain disorders during treatment including acceptance of pain, life control, affective pressure, and social support. Pain-related admissions have the strongest indirect effects among other mediators. Acceptance related to pain was not considered a traditional CBT target but could also play an important role in achieving results. In Åkerblom's research, multidisciplinary care based on CBT for 5 weeks in specialist pain units provided a significant results in the daily activities of adult patients with chronic pain. ${ }^{9}$

The duration of the study used in this article varies, from 5 weeks to 10 weeks, with a variation of 20-60 minutes per therapy session, except in studies using group therapy can take up to 5-7 hours per day. Some studies besides measuring results after being given treatment also conducted evaluations at the third and sixth months after treatment to determine long-term effectiveness after the intervention.

A qualitative study of chronic widespread pain by Bee, et al. (2016) assessed three broad contexts of chronic pain, including the context of illness that included illness perceptions and seeking help behavior. The context of identity included three themes: behavioral responses to pain, interactions between participant's identity and illness, and emotional reactions to anxiety symptoms. The context of intervention included preference for intervention and intervention experience. Greater potential has been obtained by combining telephone-based CBT interventions with prescribed exercises. The ability to adapt to chronic diseases has greatly depended on the readiness of individuals to acknowledge their weaknesses and change their lives and identities in ways that have been accepted personally and socially. Acceptance of primary care for extensive chronic pain could be maximized when physical and psychological interventions have been given simultaneously. Active intervention (physical exercise, CBT, and physical exercise plus CBT) has significantly improved clinical and global health outcomes when compared to usual care (regular general practitioner care).$^{10}$

Archer, et al. (2015) conducted cognitive behavioralbased physical therapy (CBPT) intervention in back pain patients after undergoing lumbar fusion surgery for degenerative conditions and compared them with educational interventions. The CBPT program has focused on behavior management, problem solving, cognitive restructuring, and relaxation exercises. The general decline in disability and improvement in health was found in the CBPT group to be statistically and clinically significant at the 3-month evaluation. The increase was estimated because CBPT intervention focused on reducing barriers to function functionally and walking rather than improving pain symptoms. The CBT-based rehabilitation approach also has reduced fear of moving and improving self-efficacy and performance at evaluation 6 months after surgery. CBPT program has moderate to large effects during the postoperative recovery period and this shows that CBPT has the potential to be more effective than education and traditional clinic-based rehabilitation. ${ }^{11}$

Inclusion and exclusion criteria must be considered in the selection of samples, for example in the study of Dyke, et al. (2019), which stated that the inclusion criteria were patients who had a diagnosis of chronic pain and experienced pain almost every day for at least three months. The sample exclusion criteria were those who had malignancy as the only cause of pain, clinically significant cognitive impairment, severe mental disorder or active substance abuse, unable to read, received changes in pain or psychotropic treatment in the last month before the study, and were following psychotherapy for pain management. Exclusion criteria were also important to rule out bias factors such as patients who already have primary medical conditions (e.g., chronic obstructive pulmonary disease, congestive heart failure) that could interfere with pain., 8,12

Research by Dyke, et al. (2019) mentioned that patients with lack of education, cognitive, and literacy have benefited greatly from CBT compared to educational therapy that has focused on group discussions. CBT was more structured, directed, and provided more concrete skills training than educational care. Participation in CBT did not harm patients with various potential moderators such as sociodemography or cognitive mediators. CBT intervention and education were psychosocial approach, and were very dependent on the patient's understanding of the contents of the intervention and the application of 
intervention techniques. ${ }^{12}$

From the results of the study, 6 studies showed that giving intervention in the form of cognitive behavioral approach showed significant changes in pain intensity, physical function, disability, and quality of life in patients with chronic pain. Research by Broderick, et al. (2016) showed that pain coping skill training (PCST), a form of CBT, gave significant results for pain intensity, pain coping, self-efficacy in controlling pain, disruption of pain-related activities, and reduced analgetic use. The meta-analysis by Richmond, et al. (2015) found that cognitive behavioral interventions produce long-term effects compared to waiting lists or guidelines-based active treatment. $(13,14)$

There were no significant differences between the CBT group and the psychotherapy (SC) supportive care group for pain and disability in Rutledge's study of veterans with chronic low back pain. These results were estimated to be limited to the benefits of CBT when compared to other active treatments. ${ }^{8}$

Meta-analysis study of Bernardy, et al. (2018) compared CBT with several control groups in fibromyalgia syndrome patients. In the primary outcomes of CBT versus control (waiting list, usual treatment, attention control, and active non-pharmacological therapy) it was found that both groups reported $50 \%$ or more pain reduction. CBT was statistically more likely to improve quality of life and health by more than $20 \%$. CBT was also statistically superior in reducing negative mood, disability, and fatigue. In the secondary results, it was found that both groups reported improvement in pain of $30 \%$ or more. CBT was statistically superior in reducing the mean pain intensity even though the effect size was small. CBT was statistically superior with moderate effects and clinically relevant in dealing with pain and sleep problems. ${ }^{15}$

The primary results at the end of treatment by comparing CBT with recommended pharmacological therapy (pregabalin and/or duloxetine) found that there were no statistically significant differences between the two groups in reducing pain, improving health-related quality of life, negative mood, and acceptance of therapy. Even so, CBT was superior with moderate effects and clinically relevant in coping with pain. ${ }^{15}$

\begin{tabular}{|c|c|c|c|c|c|c|c|c|c|}
\hline No & Title & $\begin{array}{l}\text { Researcher, } \\
\text { year }\end{array}$ & Design & $\begin{array}{l}\text { Population } \\
\text { \& sample }\end{array}$ & $\begin{array}{c}\text { Intervention/ } \\
\text { treatment }\end{array}$ & Control & Random & Outcome & Results \\
\hline 1. & $\begin{array}{l}\text { Cognitive } \\
\text { behavior- } \\
\text { al therapy } \\
\text { for chronic } \\
\text { pain is effec- } \\
\text { tive, but for } \\
\text { whom? }\end{array}$ & $\begin{array}{l}\text { Broderick } \\
\text { et al., } 2016\end{array}$ & $\begin{array}{l}\text { Random- } \\
\text { ized Con- } \\
\text { trolled Trial }\end{array}$ & $\begin{array}{l}\text { Patients with } \\
\text { osteoarthritis } \\
\text { (OA) of the } \\
\text { knee or hip } \\
\text { with chronic } \\
\text { pain }\end{array}$ & $\begin{array}{l}\text { Pain coping } \\
\text { skill training } \\
(\mathrm{PCST})\end{array}$ & $\begin{array}{l}\text { U s u a } 1 \\
\text { care }\end{array}$ & Yes & $\begin{array}{l}\text { 1. Pain intensity } \\
\text { 2. Physical func- } \\
\text { tioning } \\
\text { 3. Psychological } \\
\text { distress } \\
\text { 4. Coping strategies } \\
\text { 5. Catastrophizing } \\
\text { 6. Self-efficacy for } \\
\text { controlling pain } \\
\text { 7. Activity interfer- } \\
\text { ence due to pain } \\
\text { 8. Reduceuse of pain } \\
\text { medication } \\
\text { 9. Increase quality } \\
\text { of life }\end{array}$ & $\begin{array}{l}\text { Intervention } \\
>\text { Control }\end{array}$ \\
\hline 2. & $\begin{array}{l}\text { Randomized } \\
\text { Controlled } \\
\text { Trial of } \\
\text { Nurse-Deliv- } \\
\text { eredCognitive } \\
\text { Behavioral } \\
\text { Therapy Ver- } \\
\text { sus Supportive } \\
\text { Psychotherapy } \\
\text { Telehealth } \\
\text { Interventions } \\
\text { forChronic } \\
\text { BackPain }\end{array}$ & $\begin{array}{l}\text { Rutledge } \\
\text { et al., } 2018\end{array}$ & $\begin{array}{l}\text { Ran- } \\
\text { domized } \\
\text { Controlled } \\
\text { Trial }\end{array}$ & $\begin{array}{l}\text { Veterans } \\
\text { with chron- } \\
\text { ic low back } \\
\text { pain }\end{array}$ & $\begin{array}{l}\text { Cognitive } \\
\text { behavioral } \\
\text { therapy }\end{array}$ & $\begin{array}{l}\text { Support- } \\
\text { ive care }\end{array}$ & & $\begin{array}{l}\text { 1. Pain interference } \\
\text { 2. Pain intensity } \\
\text { 3. Pain-related } \\
\text { improvement } \\
\text { 4. Depression }\end{array}$ & $\begin{array}{l}\text { Intervention } \\
=\text { Control }\end{array}$ \\
\hline
\end{tabular}




\begin{tabular}{|c|c|c|c|c|c|c|c|c|c|}
\hline 3. & $\begin{array}{l}\text { Managing } \\
\text { chronic wide- } \\
\text { spread pain in } \\
\text { primary care: } \\
\text { a qualitative } \\
\text { study of } \\
\text { patient per- } \\
\text { spectives and } \\
\text { implications } \\
\text { for treatment } \\
\text { delivery } \\
\end{array}$ & $\begin{array}{l}\text { Bee et al., } \\
2016\end{array}$ & $\begin{array}{l}\text { Qualitative } \\
\text { study }\end{array}$ & $\begin{array}{l}\text { Adult pa- } \\
\text { tients with } \\
\text { chronic } \\
\text { widespread } \\
\text { pain }\end{array}$ & $\begin{array}{l}\text { 1.Telephone } \\
\text {-based CBT } \\
\text { (T-CBT) } \\
\text { 2.Prescribed } \\
\text { exercise (PE) } \\
\text { 3.Combined } \\
\text { T-CBT \& PE }\end{array}$ & $\begin{array}{l}\text { Usual } \\
\text { GPcare }\end{array}$ & Yes & $\begin{array}{l}\text { Understanding } \\
\text { potential influeces } \\
\text { on intervention } \\
\text { acceptibility }\end{array}$ & $\begin{array}{l}\text { Intervention } \\
>\text { control }\end{array}$ \\
\hline 4. & $\begin{array}{l}\text { The Mediat- } \\
\text { ing Role of } \\
\text { Acceptance } \\
\text { in Multidisci- } \\
\text { plinary Cog- } \\
\text { nitive-Behav- } \\
\text { ioral Therapy } \\
\text { for Chronic } \\
\text { Pain }\end{array}$ & $\begin{array}{l}\text { Åkerblom } \\
\text { et al., } \\
2015\end{array}$ & $\begin{array}{l}\text { Prospec- } \\
\text { tive cohort }\end{array}$ & $\begin{array}{l}\text { Adult chron- } \\
\text { ic pain }\end{array}$ & $\begin{array}{l}\text { Cognitive-be- } \\
\text { havioral } \\
\text { principles: } \\
\text { Group-based } \\
\text { sessions }+ \\
\text { practical group } \\
\text { activities }+ \\
\text { group sessions }\end{array}$ & & No & $\begin{array}{l}\text { 1. Pain interference } \\
\text { 2. Pain intensity } \\
\text { 3. Depression } \\
\text { 4. Pain-related } \\
\text { acceptance } \\
\text { 5. Life control } \\
\text { 6. Affective distress } \\
\text { 7. Social support }\end{array}$ & Positive \\
\hline 5. & $\begin{array}{l}\text { The Effec- } \\
\text { tiveness of } \\
\text { Cognitive } \\
\text { Behavioural } \\
\text { Treatment for } \\
\text { Non-Specific } \\
\text { Low Back } \\
\text { Pain:A } \\
\text { Systematic } \\
\text { Review and } \\
\text { Meta-Anal- } \\
\text { ysis }\end{array}$ & $\begin{array}{l}\text { Richmond } \\
\text { et al., } 2015\end{array}$ & $\begin{array}{l}\text { Meta- } \\
\text { analysis }\end{array}$ & $\begin{array}{l}\text { Patients with } \\
\text { non-specific } \\
\text { low back } \\
\text { pain }\end{array}$ & $\begin{array}{l}\text { Cognitive } \\
\text { behavioral } \\
\text { interventions }\end{array}$ & $\begin{array}{l}\text { Waiting } \\
\text { list (WL) } \\
\text { Usual } \\
\text { care(UC) } \\
\text { and/or } \\
\text { guide- } \\
\text { line-based } \\
\text { active } \\
\text { treatment } \\
\text { (GAT) }\end{array}$ & & $\begin{array}{l}\text { 1. Pain } \\
\text { 2. Disability } \\
\text { 3. Quality of life } \\
\text { 4. Work disability }\end{array}$ & $\begin{array}{l}\text { Intervention } \\
>\text { control }\end{array}$ \\
\hline 6. & $\begin{array}{l}\text { Cognitive- } \\
\text { behavioral } \\
\text { based physi- } \\
\text { cal therapy for } \\
\text { patients with } \\
\text { chronic pain } \\
\text { undergoing } \\
\text { lumbar spine } \\
\text { surgery: a } \\
\text { randomized } \\
\text { controlled trial }\end{array}$ & $\begin{array}{l}\text { Archer et } \\
\text { al., } 2015\end{array}$ & $\begin{array}{l}\text { Random- } \\
\text { ized } \\
\text { Controlled } \\
\text { Trial }\end{array}$ & $\begin{array}{l}\text { Patients with } \\
\text { chronic pain } \\
\text { undergoing } \\
\text { lumbar } \\
\text { spine } \\
\text { surgery }\end{array}$ & $\begin{array}{l}\text { Cognitive } \\
\text { behavioral } \\
\text { physical } \\
\text { therapy } \\
\text { (CBPT) }\end{array}$ & Education & & $\begin{array}{l}\text { 1. Pain } \\
\text { 2. Disability } \\
\text { 3. General health } \\
\text { 4. Physical perfor- } \\
\text { mance }\end{array}$ & $\begin{array}{l}\text { Intervention } \\
>\text { control }\end{array}$ \\
\hline 7. & $\begin{array}{l}\text { Heterogeneity } \\
\text { of treatment } \\
\text { effects in a } \\
\text { randomized } \\
\text { trial of literacy } \\
\text { adapted group } \\
\text { cognitive } \\
\text { behavioral } \\
\text { therapy, pain } \\
\text { psychoedu- } \\
\text { cation, and } \\
\text { usual medical } \\
\text { care for multi- } \\
\text { ply disadvan- } \\
\text { taged patients } \\
\text { with chronic } \\
\text { pain }\end{array}$ & $\begin{array}{l}\text { Dyke et } \\
\text { al., } 2019\end{array}$ & $\begin{array}{l}\text { Random- } \\
\text { ized } \\
\text { Controlled } \\
\text { Trial }\end{array}$ & $\begin{array}{l}\text { Patients with } \\
\text { chronic pain }\end{array}$ & $\begin{array}{l}\text { 1.Cognitive } \\
\text {-behavioral } \\
\text { therapy (CBT) } \\
\text { 2. Pain } \\
\text { education } \\
\text { group(EDU) }\end{array}$ & $\begin{array}{l}\text { Usual } \\
\text { medical } \\
\text { care(UC) }\end{array}$ & & $\begin{array}{l}\text { 1. Pain intensity and } \\
\text { interference } \\
\text { 2. Depression }\end{array}$ & $\begin{array}{l}\text { Intervention } \\
>\text { control }\end{array}$ \\
\hline
\end{tabular}




\begin{tabular}{|c|c|c|c|c|c|c|c|c|}
\hline 8. & $\begin{array}{l}\text { Efficacy, } \\
\text { acceptability } \\
\text { and safety } \\
\text { of cognitive } \\
\text { behavioural } \\
\text { therapies in } \\
\text { fibromyalgia } \\
\text { syndrome- } \\
\text { A system- } \\
\text { atic review } \\
\text { and meta } \\
\text { analysis of } \\
\text { randomized } \\
\text { controlled } \\
\text { trials }\end{array}$ & $\begin{array}{l}\text { Bernardy } \\
\text { et al., } \\
2018\end{array}$ & $\begin{array}{l}\text { Meta } \\
\text { analysis }\end{array}$ & $\begin{array}{l}\text { Patients } \\
\text { with fibro- } \\
\text { myalgia } \\
\text { syndrome }\end{array}$ & $\begin{array}{l}\text { Cognitive } \\
\text { behavioral } \\
\text { therapy: } \\
\text { Operant thera- } \\
\text { py, Traditional } \\
\text { CBT, Self } \\
\text { management } \\
\text { education } \\
\text { programmes, } \\
\text { Acceptance- } \\
\text { based CBT }\end{array}$ & $\begin{array}{l}\text { Attention } \\
\text { control/ } \\
\text { Waiting } \\
\text { list/ } \\
\text { Treat- } \\
\text { ment as } \\
\text { usual/No } \\
\text { therapy/ } \\
\text { Any oth- } \\
\text { er active } \\
\text { therapy }\end{array}$ & $\begin{array}{l}\text { 1.Primary outcome: } \\
\text { Pain relief, improve- } \\
\text { ment of health-re- } \\
\text { lated quality of life, } \\
\text { negative mood, } \\
\text { disability, fatigue, } \\
\text { acceptability, safety. } \\
\text { 2.Secondary out- } \\
\text { come: Paien relief, } \\
\text { mean pain intensity, } \\
\text { coping with pain, } \\
\text { sleep problems. }\end{array}$ & $\begin{array}{l}\text { Intervention } \\
>\text { Control }\end{array}$ \\
\hline
\end{tabular}

\section{Discussion}

The study examined in these articles showed that one of the strategies for chronic pain management was to use psychological interventions with cognitive behavioral approaches. Although not all studies produced significant values on all aspects of measurement parameters, this conclusion can be drawn based on pain coping parameters in patients with chronic pain. The improvement in symptoms, disability, limited functioning, and pain with CBT intervention plus active physical therapy was associated with improved patient confidence regarding pain and pain management strategies before and after CBT interventions that affected the catastrophization of pain. ${ }^{16}$

CBT consists of three basic therapeutic components, including patient's education related to realistic expectations and goals based on chronic pain conditions, helping patient's self-regulation in responding to stress with behavioral coping skills, and handling the maladaptive thinking process with cognitive coping skills. The aim of the CBT approach is to independently improve self-efficacy in pain management. ${ }^{17,18}$

The intervention itself has variations in content, duration, and format. The implementation of CBT intervention was closely related to the competency of the therapist and the amount of care provided. The therapist's competency was positively related to better outcomes in patients who followed the CBT interventions. The therapist's behavior and therapeutic ability to assess which treatments were best given to patients would greatly help patients with chronic pain. ${ }^{16}$

In predicting therapeutic results in patients with chronic pain, the clinical experiences of therapist was not very influential. Nevertheless the manual-based method of giving CBT, which was very dependent on the skills of the therapist gave greater results. Many patients with chronic pain who took psychological care were due to unsuccessful medical treatment. Patients' expectations for treatment could also affect the outcome of therapy. Pain reduction was not the goal of treatment given by CBT, but when patients could accept the pain condition, they would learn to improve their functional abilities and quality of life even in conditions of pain. ${ }^{19}$
Patients with chronic pain usually regard pain as a stressful situation, and CBT helps in more positive and realistic cognitive assessment of the situation. Neuroimaging research has also proven the theory and found that negative cognition could increase pain signals and altered brain circuits related to pain perception. ${ }^{20}$ The treatment of chronic pain with CBT caused a grey substance increase in some areas of the brain including prefrontal and parietal areas. In addition, the decline in pain catastrophization was related to the increase of grey substance in the parietal and prefrontal areas. ${ }^{21}$ The decline in catastrophization and the increase in positive expectations from pain control mediated the effect of CBT on improvements in pain behavior, activity, and symptoms of depression. ${ }^{22}$

Another important challenge was the involvement of patients in therapy. Compliance of patients in treatment was not only by attending therapy sessions but also actively participating in therapy (for example, completing homework, practicing skills learned, and applying skills in real life). In a review of psychotherapy, better results were related to compliance in doing homework. ${ }^{16}$

Only one study evaluated CBT follow-up in the third and sixth month after intervention. Postoperative rehabilitation with a cognitive behavioral approach increased self-efficacy and performance at the sixth month of follow-up. For the future, the significance of CBT on pain intensity at 6 to 12 months post-treatment needs to be further investigated including the types of programs needed to maintain and stabilize pain-related improvement.

Chronic pain management with cognitive and behavioral approaches is very possible to be done in a hospital or rehabilitation clinic with trained therapists. Therefore, it is necessary for doctors to be able to identify patients who failed to respond adequately to biological approaches and are likely to respond with behavioral approaches.

\section{Conclusion}

The implementation of cognitive behavioral therapy for pain management with delivery methods in the form of traditional CBT, telephone-based CBT, coping skills training, cognitive behavioral-based physical 
therapy or CBT-based self-management can be applied to outpatients with chronic pain. Based on this review, cognitive behavioral approaches can provide greater benefits for improving physical function when combined with other modalities in the management of chronic pain.

\section{Conflict of Interest}

The author stated there is no conflict of interest

\section{References}

1. Sturgeon JA. Psychological therapies for the management of chronic pain. Psychol Res Behav Manag. 2014;7:115-24.

2. Majeed MH, Ali AA, Sudak DM. Psychotherapeutic interventions for chronic pain: Evidence, rationale, and advantages. Int J Psychiatry Med. 2018;0(0):1-10.

3. Skinner M, Wilson HD, Turk DC. Cognitive-Behavioral Perspective and Cognitive-Behavioral Therapy for People With Chronic Pain: Distinctions, Outcomes, and Innovations. J Cogn Psychother. 2012;26(2):93-113.

4. Kerns RD, Sellinger J, Goodin BR. Psychological Treatment of Chronic Pain. Annu Rev Clin Psychol. 2011;7:411-34.

5. Moseley GL, Vlaeyen JWS. Beyond nociception: the imprecision hypothesis of chronic pain. Pain. 2015;156(1):35-8.

6. Sheng J, Liu S, Wang Y, Cui R, Zhang X. The Link between Depression and Chronic Pain: Neural Mechanisms in the Brain. Neural Plast. 2017;

7. Gatchel RJ, Mcgeary DD, Mcgeary CA, Lippe B. Interdisciplinary Chronic Pain Management. Past, Present, and Future. Am Psychol. 2014;69(2):119-30.

8. Rutledge T, Atkinson JH, Psyd RH, Chircop-rollick T, Andrea JD, Garfin SR, et al. Randomized Controlled Trial of Nurse-Delivered Cognitive Behavioral Therapy Versus Supportive Psychotherapy Telehealth Interventions for Chronic Back Pain. J Pain. 2018;

9. Akerblom S, Perrin S, Fischer MR, McCracken LM. The Mediating Role of Acceptance in Multidisciplinary Cognitive-Behavioral Therapy for Chronic Pain. J Pain. 2015;16(7):606-15.

10. Bee P, Mcbeth J, Macfarlane GJ, Lovell K. Managing chronic widespread pain in primary care: a qualitative study of patient perspectives and implications for treatment delivery. BMC Musculoskelet Disord. 2016;17(354).

11. Archer KR, Devin CJ, Vanston SW, Koyama T, Phillips S, George SZ, et al. Cognitive-behavioral based physical therapy for patients with chronic pain undergoing lumbar spine surgery: a randomized controlled trial. J Pain. 2015;

12. Dyke BP Van, Newman AK, Morais CA, Burns JW, Eyer JC,
Thorn BE. Heterogeneity of treatment effects in a randomized trial of literacy-adapted group cognitive-behavioral therapy, pain psychoeducation, and usual medical care for multiply disadvantaged patients with chronic pain. J Pain. 2019;

13. Broderick JE, Keefe FJ, Schneider S, Junghaenel DU, Schwartz JE, Kaell AT, et al. Cognitive behavioral therapy for chronic pain is effective, but for whom? Int Assoc Study Pain. 2016;

14. Richmond H, Hall AM, Copsey B, Hansen Z, Williamson E, HoxeyThomas N, et al. The Effectiveness of Cognitive Behavioural Treatment for Non-Specific Low Back Pain: A Systematic Review and Meta-Analysis. PLoS One. 2015;10(8):1-20.

15. Bernardy K, Klose P, Welsch P, H€auser W. Efficacy, acceptability and safety of cognitive behavioural therapies in fibromyalgia syndrome - A systematic review and meta-analysis of randomized controlled trials. Eur J Pain. 2018;22:242-60.

16. Ehde DM, Dillworth TM, Turner JA. Cognitive-Behavioral Therapy for Individuals With Chronic Pain. Efficacy, Innovations, and Directions for Research. Am Psychol. 2014;69(2):153-66.

17. Okifuji A, Neikrug A. Update and future perspective of behavioral medicine in the treatment for chronic pain. Pain Manag. 2019;

18. Knoerl R, Smith EML, Weisberg J. Chronic Pain and Cognitive Behavioral Therapy: An Integrative Review. West J Nurs Res. 2015;1-33.

19. Vlaeyen JWS, Morley S. Cognitive-Behavioral Treatments for Chronic Pain: What Works for Whom? Clin J Pain. 2005;21(1):1-8.

20. Day MA, Thorn BE, Kapoor S. A qualitative analysis of a randomized controlled trial comparing a cognitive-behavioral treatment with education. J Pain. 2012;12(9):941-52.

21. Seminowicz DA, Shpaner M, Keaser ML, Krauthamer GM, Mantegna J, Dumas JA, et al. Cognitive-Behavioral Therapy Increases Prefrontal Cortex Gray Matter in Patients With Chronic Pain. J Pain. 2013;14(12):1573-84.

22. Smeets RJEM, Vlaeyen JWS, Hidding A, Kester ADM, Heijden GJMG Van Der, Geel ACM Van, et al. Cognitive-behavioral, physical, or both? First direct post-treatment results from a randomized controlled trial. BMC Musculoskelet Disord. 2006;7(5):1-16. 